\section{SCALING NEW HEIGHTS: FIRST RECORD OF BOULENGER'S LAZY TOAD SCUTIGER BOULENGERI (AMPHIBIA: ANURA: MEGOPHRYIDAE) FROM HIGH ALTITUDE LAKE IN SIKKIM HIMALAYA, INDIA}

\author{
Barkha Subba $^{1}$, G. Ravikanth ${ }^{2} \&$ N.A. Aravind ${ }^{3}$ \\ ${ }^{1,2,3}$ Ashoka Trust for Research in Ecology and the Environment (ATREE), Suri Sehgal Centre for Biodiversity and \\ Conservation, Royal Enclave, Srirampura, Jakkur PO, Bengaluru, Karnataka 560064, India \\ ${ }^{1}$ Manipal University, Manipal, Karnataka 576104, India \\ ${ }^{1}$ barkhasubba@gmail.com (corresponding author), ${ }^{2}$ gravikanth@atree.org, ${ }^{3}$ aravind@atree.org
}

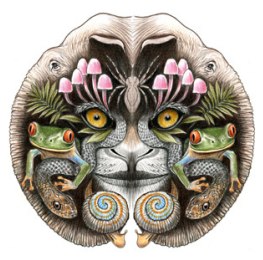

ISSN 0974-7907 (Online) ISSN 0974-7893 (Print)

OPEN ACCESS
Abstract: Frogs in the genus Scutiger of the family Megophryidae are the highest altitude frogs in the world, and are endemic to eastern Himalaya. Here, we report the occurrence of Scutiger boulenger (Bedriaga, 1898) in one of the highest altitude lakes in the world, Lake Gurudongmar. This is the first report of Scutiger boulengeri from India and the first record of any amphibian species to be found at an altitude as high as $5270 \mathrm{~m}$, thus setting a world record for the highest altitude frog. Scutiger sikimmensis (Blyth, 1855) is another species of the genus Scutiger found in this region. This species is often confused with Scutiger boulengeri due to similar morphology and habitat overlap. We provide a detailed account of both S. boulengeri and S. sikimmensis based on morphology and molecular identification techniques.

Keywords: Amphibian, Sikkim, glacier, lake Gurudongmar, Scutiger boulengeri, Scutiger sikimmensis.
The Himalayan region is one of the 35 biodiversity hotspots of the World (Mittermeier et al. 2004). This region has a high altitudinal range from $300-8598 \mathrm{~m}$ and harbors several endemic taxa. The high altitude flora and fauna of this region are important for global biological diversity because there are very few places on Earth with such a unique ecosystem (Mani 1994; Shrestha et al. 2012). In Sikkim Himalaya, 23 species of amphibians are known (Chettri et al. 2011); some species have narrow distribution range, and for many, there is still a lack of knowledge about their distribution, life history and ecology (Acharya \& Vijayan 2011; Chettri et. al. 2011). These areas, due to their inaccessibility, have not been surveyed extensively, especially for amphibians.
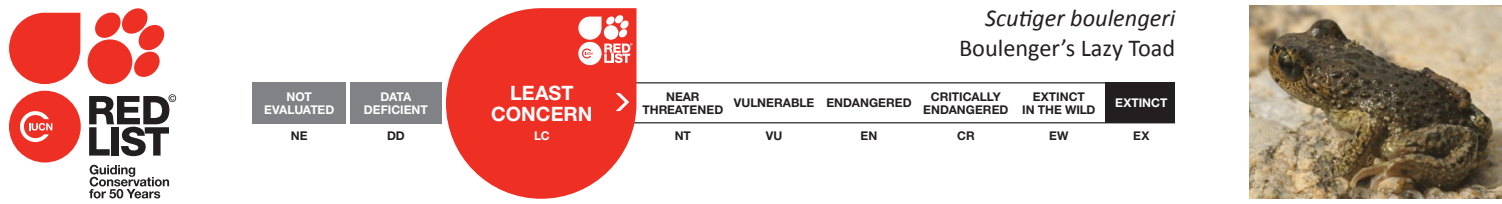

DOI: http://dx.doi.org/10.11609/JoTT.04325.7655-63 | ZooBank: urn:Isid:zoobank.org:pub:332D6D84-06AD-40E6-A5E8-7807C6CE3BBF

Editor: Neelesh Dahanukar, IISER, Pune, India.

Date of publication: 26 August 2015 (online \& print)

Manuscript details: Ms \# 04325 | Received 29 May 2015 | Final received 10 August 2015 | Finally accepted 14 August 2015

Citation: Subba, B., G. Ravikanth \& N.A. Aravind (2015). Scaling new heights: first record of Boulenger's Lazy Toad Scutiger boulengeri (Amphibia: Anura: Megophryidae) from high altitude lake in Sikkim Himalaya, India. Journal of Threatened Taxa 7(10): 7655-7663; http://dx.doi.org/10.11609/JoTT.04325.7655-63

Copyright: (C) Subba et al. 2015. Creative Commons Attribution 4.0 International License. JoTT allows unrestricted use of this article in any medium, reproduction and distribution by providing adequate credit to the authors and the source of publication.

Funding: Critical Ecosystem Partnership Fund (CEPF) [CEPF Small Grant 2009 (1 Dec 2009 to 31 Dec 2011)] and Madras Crocodile Bank Trust (MCBT) HCRF-2011/MCBT (1 May 2012 to 30 April 2013).

Competing interests: The author declares no competing interests.
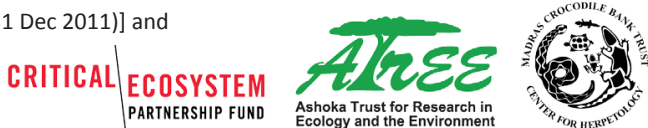

Acknowledgements: Authors are thankful to friends and volunteers who helped in the field. We would like to thank Mrs. Usha Lachungpa and the Sikkim Forest Department for facilitating and providing permit for the research work. We would also like to thank A. Dubois and A. Ohler for confirming the identification of frogs through examination of the preserved specimen and photographs of live specimen, Priti Hebbar for facilitating the lab work and Sandeep Sen for his inputs in the manuscript. We acknowledge CEPF and MCBT for funding this project. We would also like to thank anonymous reviewers for their critical review of the manuscript. 
Among the several restricted taxa in the Himalayan region is the genus Scutiger, belonging to the family Megophryidae. It is one of the most diverse families of non-neobatrachian frogs. Twenty species of Scutiger occur in the high altitudes of the Tibetan plateau in southwestern China, Myanmar, Nepal and northern India (Frost 2015). One interesting species in this genus Scutiger boulengeri, commonly known as Boulenger's Lazy Toad or Xizang Alpine Toad, holds the record for being the highest altitude frog in the world (Hock 1964), found at altitudes up to $5100 \mathrm{~m}$. Scutiger boulengeri is known to occur in northwestern Nepal, and southeastern Qinghai, eastern \& southern part of Xizang, southern Gansu and northwestern Sichuan provinces in western China (Ohler et al. 2014).

Another species of Scutiger found in Sikkim is Scutiger sikimmensis, commonly known as the Sikkim Snow Toad. Scutiger boulengeri can be easily mistaken for S. sikimmensis, as they are morphologically similar. Scutiger sikimmensis is very common in the high altitudes of Sikkim Himalaya. In this paper, using an integrative taxonomic approach, we delineate $S$. boulengeri from S. sikimmensis and hence confirm the presence of two species of Scutiger in Sikkim.

\section{Materials AND MethodS \\ Sampling}

A total of four individuals of $S$. boulengeri and four individuals of S. sikimmensis collected from five locations in Sikkim were included in this study (Fig. 1). The specimens are presently deposited in ATREE museum, Bangalore, India and will be deposited in the Natural History Museum of Sikkim as per the agreement with the forest department (15/DIR(REE)/FEWMD/GOS/2011) once the museum becomes functional. Latitude and longitude were recorded using Garmin eTrex Vista H GPS with the datum set to WGS 84 .

Specimens were fixed in $5 \%$ formalin for 12 to 18 hours and were subsequently transferred to $70 \%$ ethanol. Samples for molecular analysis were taken from hind limb muscle tissue, and were preserved in $70 \%$ ethanol prior to fixing in formalin.

\section{Morphometry}

Morphometric data were recorded using digital caliper $(+/-0.1 \mathrm{~mm})$. All measurements follow Ohler et al. (2011). The measurements were used to compute the Principle Component Analysis (PCA) between the two species. For PCA, data were transformed into their base 10 logarithm to correct for size and analysis was performed in PAST 3 (Hammer et al. 2001).
Body: SVL snout-vent length. Head: EL eye length; EN distance from anterior corner of eye to posterior edge of nostril; $\mathrm{HL}$ head length from posterior corner of mandible to tip of snout; HW head width, at the angle of jaws; IBE distance between posterior corners of eyes; IFE distance between anterior corners of eyes; IN internarial distance; IUE minimum distance between upper eyelids; MBE distance from posterior corner of mandible to posterior corner of eye; MFE distance from posterior corner of mandible to anterior corner of eye; MN distance from posterior corner of mandible to posterior edge of nostril; NS distance from anterior edge of nostril to tip of snout; SL distance from anterior corner of eye to tip of snout; UEW maximum width of upper eyelid. Forelimb: FLL forearm length, from elbow to base of outer palmar tubercle; HAL hand length, from base of outer palmar tubercle to tip of third finger; TFL third finger length, from articulation of proximal and intermediate phalange. Hindlimb: FFTF distance from maximum incurvation of web between fourth and fifth toe to tip of fourth toe, toes being spread; FL thigh length, from vent to knee; FOL foot length, from base of inner metatarsal tubercle to tip of fourth toe; FTL fourth toe length, from articulation of proximal and intermediate phalange; ITL inner toe length; MTFF distance from distal edge of metatarsal tubercle to maximum incurvation of web between fourth and fifth toe, toes being spread; MTTF distance from distal edge of metatarsal tubercle to maximum incurvation of web between third and fourth toe, toes being spread; TFOL length of tarsus and foot from base of tarsus to tip of fourth toe; TFTF distance from maximum incurvation of web between third and fourth toe to tip of fourth toe, toes being spread; TL shank length.

\section{DNA extraction, amplification and sequencing}

Genomic DNA extraction was carried out using thigh tissue samples preserved in $70 \%$ alcohol. The extraction was carried out following the protocol described in Vences et al. (2012). We used the primers 16Sar-L 5'-CGCCTGTTTATCAAAAACAT-3' and 16Sbr-H 5'-GAGGGTGACGGGCGGTGTGT-3' to amplify the fragment of the mitochondrial 16S ribosomal RNA gene following Hebbar et al. (2015). The PCR cycling procedure was as follows; initial denaturation at $94^{\circ} \mathrm{C}$ for $3 \mathrm{mins}, 36$ cycles of $94^{\circ} \mathrm{C}$ for $45 \mathrm{sec}, 55^{\circ} \mathrm{C}$ for $1 \mathrm{~min}$ and $72^{\circ} \mathrm{C}$ for $45 \mathrm{sec}$ and a final extension step at $72^{\circ} \mathrm{C}$ for 10 mins. Amplified PCR products were sent for purification and sequencing to AMNION Sequencing Service, Bangalore, India. 


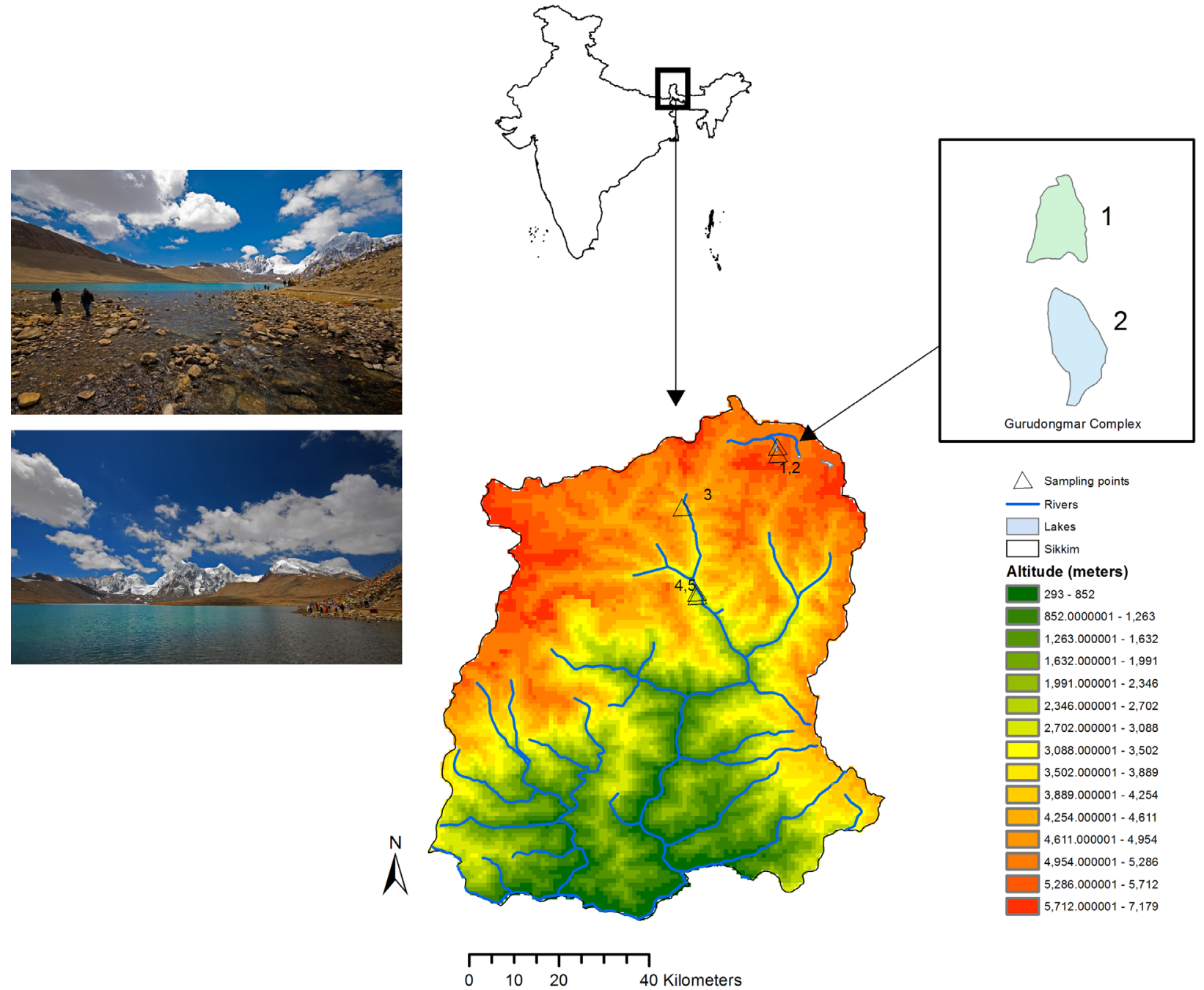

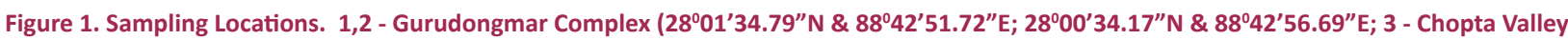

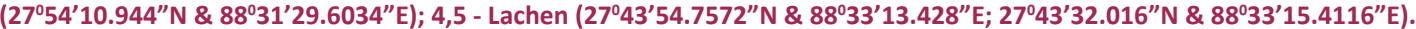

\section{Sequence Data Analysis}

The sequence chromatogram obtained were edited using Chromas (Version 2.4, Copyright 1998-2012; Technelysium Pvt. Ltd., South Brisbane, Australia) and the BLAST (Altschul et al. 1990) analysis was performed with the sequences as queries to identify similar nucleotide sequences in the NCBI sequence database. Along with the sequences with highest homology, maximum query coverage and maximum score, the available DNA sequences of Scutiger species were downloaded as FASTA format from the GenBank. We obtained the sequences of S. glandulatus and S. boulengeri from the GenBank and these were included in the analyses (Appendix 1). These sequences along with the ones obtained from the current study were aligned using MUSCLE (Edgar 2004) nested in MEGA 5 (Tamura et al. 2011). All sequences were deposited in GenBank (Accession no. KR781480 -
KR781486). The best fit model of sequence evolution/ DNA substitution was determined using J-Model Test Version 2.1.7 (Darriba et al. 2012). The DNA substitution models chosen using the Akaike information criterion (AIC) in jModelTest ver. 2.1.7 was GTR+I+G for $16 \mathrm{~S}$ rRNA dataset (AIC value $=2881.698,-\operatorname{lnL}=1396.84880$ ) . Phylogenetic tree were constructed using Bayesian and Likelihood methods implemented in MrBayes Version 3.2 (Ronquist et al. 2011) and RaxML Version 1.3.1 (Silvestro \& Michalak 2012) respectively. Ten million generations were executed in MrBayes out of which $10 \%$ (10,000 trees) were discarded as 'burn in'. The bootstrap support was determined for 1000 pseudoreplicates for the $\mathrm{ML}$ tree using rapid bootstrapping in RAxML Version 1.3.1. The convergence of MCMC chains was determined visually by the software TRACER Version 1.6 and by analyzing Potential Side Reduction Factor (PSRF). The 
final tree was visualized using FIGTREE (Rambaut 2009).

\section{RESULTS AND DISCUSSION}

Four males and four females of the Scutiger species were used for both the morphometric as well as genetic analysis. Of these, two males and two females belonged to each of the two species, $S$. boulengeri and S. sikimmensis. Scutiger sikimmensis was collected from its type locality, Sikkim (Theobald 1868) and this is the first sequence submission of this species to GenBank. The morphometeric data analysis conducted confirmed that the individuals of the genus Scutiger found in Sikkim are two distinct species namely $S$. boulengeri and S. sikimmensis (Table 1; Image 1). The sequence analysis confirmed that these are two distinct species (Fig. 2). The PCA analysis based on morphometric data also supported the genetic analysis (Fig. 3). Thus, both morphological characters as well as molecular tools clearly established that these are two distinct species of Scutiger.

The obtained sequences of individual species of Scutiger comprised of $484 \mathrm{bp}$ out of which there were 54 parsimony informative sites. The phylogenetic tree based on Maximum Likelihood analysis showed distinct clusters corresponding to S. sikimmensis, S. glandulatus and S. boulengeri. The nodes with poor support $(<50 \%)$ are not shown (Fig. 2). The sequences, which were attributed to $S$. boulengeri based on morphological characters, namely KR781481, KR781482 and KR781483, formed a distinct cluster with S. boulengeri reported from China, thus conforming the identity of the species. The pairwise genetic distance (K2P) between $S$. boulengeri from the current study and Fu et al. (2007) study were equal to or less than 3\% (Table 2 ).

Table 1. Morphometric data of S. boulengeri and S. sikkimensis. All measurements are in $\mathrm{mm}$.

\begin{tabular}{|c|c|c|c|c|c|c|c|c|}
\hline & \multicolumn{4}{|c|}{ Scutiger boulengeri } & \multicolumn{4}{|c|}{ Scutiger sikimmensis } \\
\hline Characters & Male \#1 & Male \#2 & Female \#1 & Female \#2 & Male \#1 & Male \#2 & Female \#1 & Female \#2 \\
\hline SVL & 48.5 & 48.9 & 52.0 & 53.0 & 48.0 & 48.5 & 51.0 & 52.0 \\
\hline HW & 16.3 & 16.6 & 17.8 & 18.0 & 16.5 & 16.9 & 17.7 & 17.9 \\
\hline $\mathrm{HL}$ & 13.6 & 14.5 & 13.3 & 13.5 & 13.5 & 14.0 & 13.0 & 13.2 \\
\hline MN & 11.7 & 11.7 & 11.9 & 11.9 & 12.0 & 12.0 & 12.0 & 12.0 \\
\hline MFE & 8.2 & 9.1 & 9.1 & 9.2 & 8.5 & 8.8 & 8.8 & 8.7 \\
\hline MBE & 4.4 & 4.4 & 4.8 & 4.9 & 4.6 & 5.1 & 5.0 & 5.1 \\
\hline IFE & 7.3 & 7.6 & 7.0 & 7.2 & 7.4 & 7.9 & 7.1 & 7.3 \\
\hline IBE & 13.1 & 13.2 & 13.4 & 13.6 & 12.9 & 13.7 & 13.1 & 13.2 \\
\hline IN & 4.0 & 4.1 & 4.0 & 4.1 & 3.9 & 4.2 & 4.0 & 4.0 \\
\hline EN & 3.3 & 3.3 & 3.4 & 3.4 & 3.0 & 3.0 & 3.0 & 3.0 \\
\hline EL & 5.3 & 5.6 & 6.0 & 6.1 & 5.0 & 5.6 & 5.6 & 5.8 \\
\hline SN & 2.1 & 2.1 & 2.2 & 2.2 & 2.5 & 2.5 & 2.5 & 2.6 \\
\hline SL & 6.1 & 6.1 & 6.1 & 6.2 & 5.6 & 5.7 & 5.6 & 5.7 \\
\hline IUE & 4.0 & 4.3 & 4.3 & 4.3 & 4.4 & 4.4 & 4.4 & 4.4 \\
\hline UEW & 2.8 & 3.4 & 4.0 & 4.0 & 3.0 & 3.7 & 3.8 & 3.7 \\
\hline HAL & 11.3 & 11.3 & 11.7 & 11.8 & 12.0 & 12.4 & 12.4 & 12.5 \\
\hline FLL & 12.3 & 13.0 & 12.9 & 13.0 & 12.1 & 12.0 & 12.0 & 12.0 \\
\hline TFL & 7.5 & 7.4 & 7.5 & 7.5 & 7.0 & 7.0 & 6.9 & 7.0 \\
\hline $\mathrm{FL}$ & 19.1 & 20.4 & 18.6 & 18.7 & 20.7 & 21.6 & 19.7 & 19.8 \\
\hline TL & 18.0 & 18.8 & 16.9 & 17.0 & 18.4 & 18.3 & 16.4 & 16.5 \\
\hline TFOL & 29.5 & 32.8 & 31.5 & 32.2 & 31.8 & 32.0 & 30.0 & 31.0 \\
\hline FOL & 21.2 & 22.5 & 22.6 & 22.6 & 20.0 & 20.0 & 20.0 & 20.0 \\
\hline FTL & 12.0 & 12.0 & 12.3 & 12.3 & 12.0 & 12.0 & 12.0 & 12.0 \\
\hline ITL & 4.5 & 4.5 & 4.3 & 4.5 & 4.1 & 4.0 & 3.9 & 4.0 \\
\hline MTTF & 13.1 & 13.2 & 13.3 & 13.4 & \multicolumn{4}{|c|}{ Rudimentary webbing } \\
\hline TFTF & 7.5 & 7.6 & 7.9 & 8.0 & & & & \\
\hline MTFF & 13.6 & 13.6 & 14.0 & 14.0 & & & & \\
\hline FFTF & 8.9 & 8.8 & 9.0 & 9.0 & & & & \\
\hline
\end{tabular}



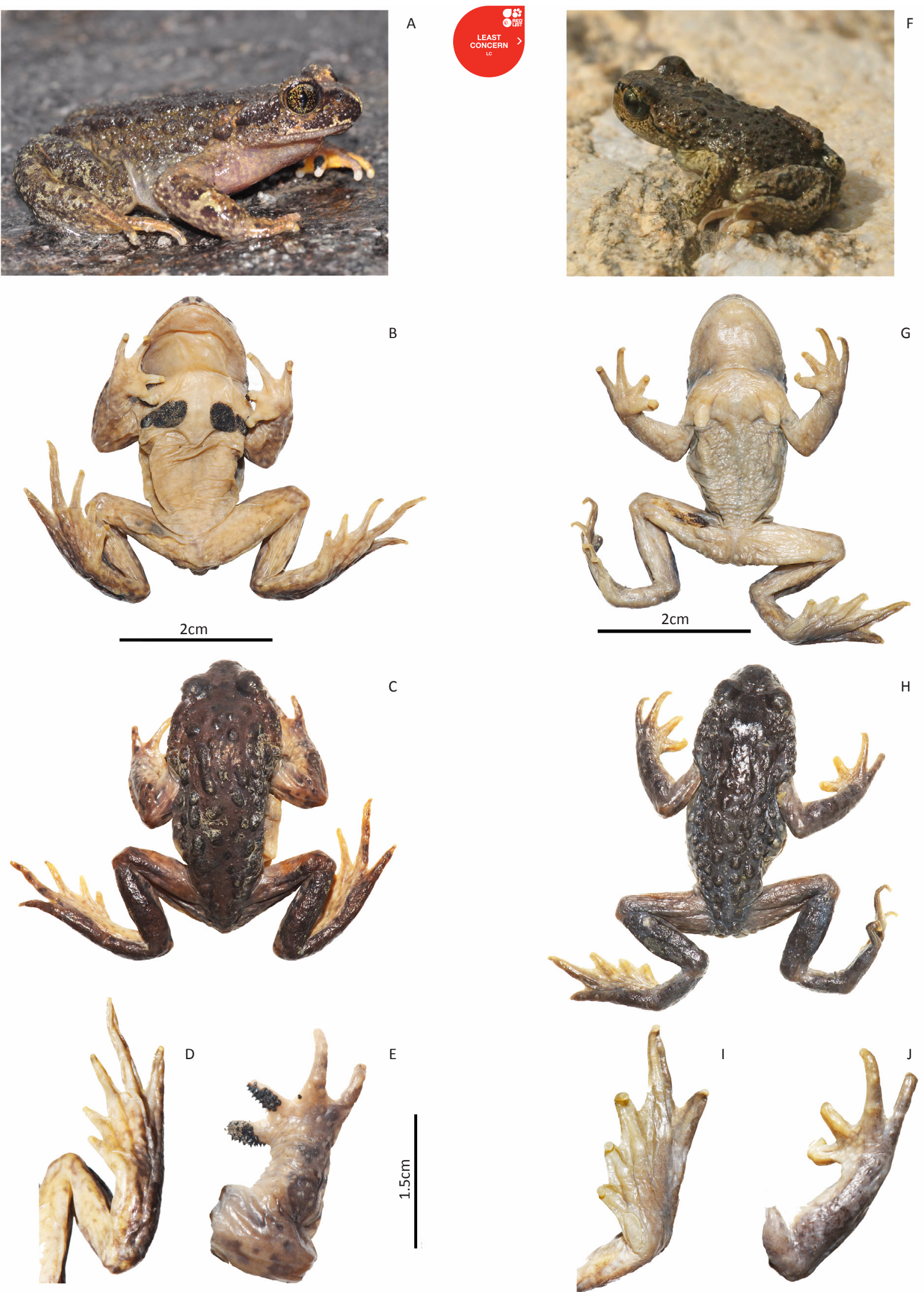

Image 1. A-E - Scutiger sikimmensis. A - Live specimen, (B-E - Preserved specimen) B - ventral view, C - dorsal view, D - ventral view of left foot, E - dorsal view of right hand; F-J - Scutiger boulengeri. F - live specimen, (G-J - preserved specimen) G - ventral view, H - dorsal view, $\mathrm{I}$ - dorsal view of left foot, J - dorsal view of right hand. 


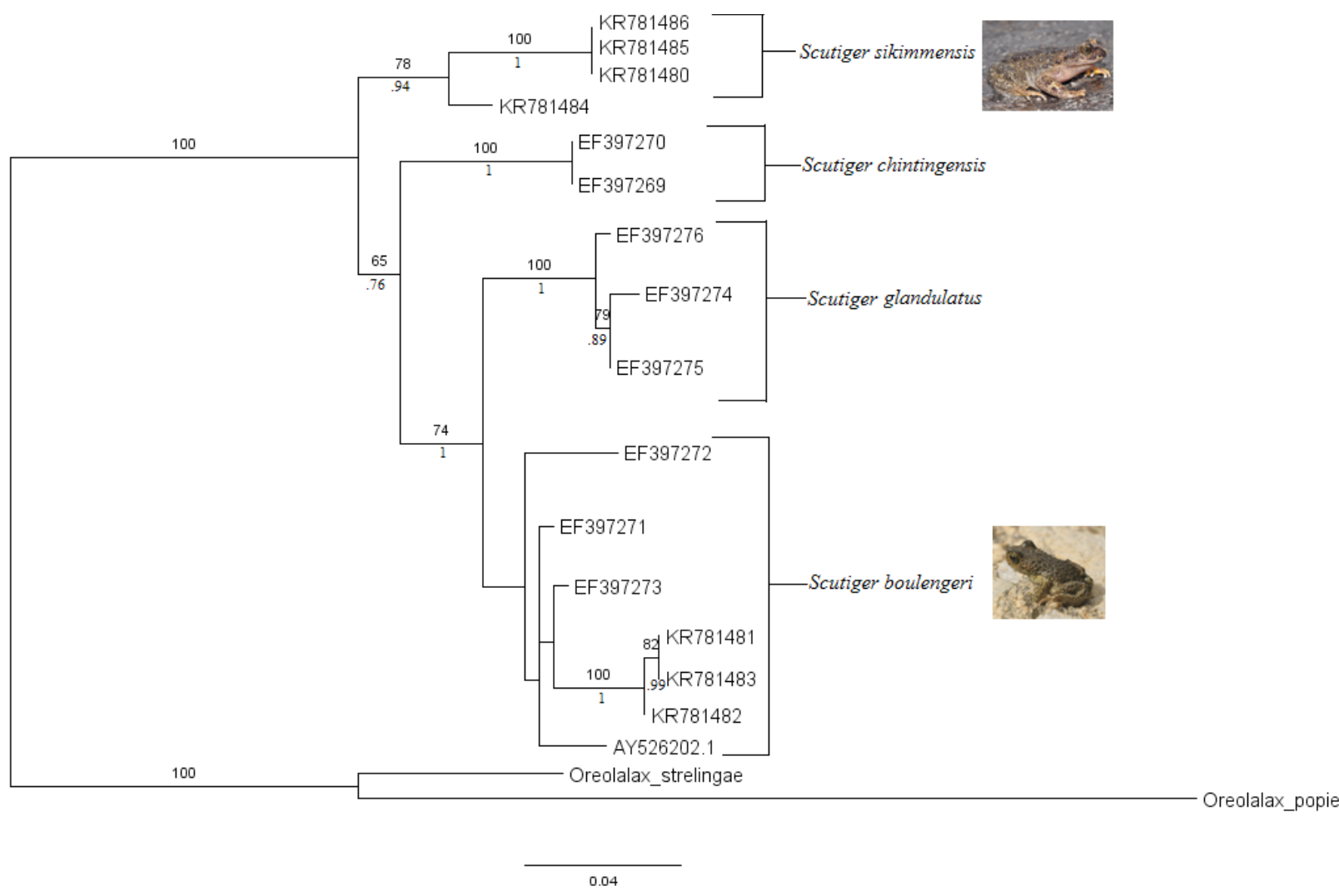

Figure 2. Molecular phylogenetic tree of S. boulengeri, S. glandulatus and S. sikimmensis using 16SrRNA dataset with Oreolalax spp. as outgroup. The values above the branches are Maximum Likelihood Bootstrap and below the branches are Bayesian Posterior Probability (BPP) generated using MrBayes. The nodes having value below 50\% bootstrap and BPP 0.75 are not shown

Genus Scutiger is restricted to the high altitudes of the Himalaya. Here we report the occurrence of $S$. boulengeri for the first time in India, from a high altitude lake in Sikkim. This species was found in the glacier Lake Gurudongmar Complex 1 and $2\left(28^{\circ} 01^{\prime} 34.79^{\prime \prime} \mathrm{N}\right.$ \& $\left.88^{\circ} 42^{\prime} 51.72^{\prime \prime} \mathrm{E} ; 28^{\circ} 00^{\prime} 34.17^{\prime \prime} \mathrm{N} \& 88^{\circ} 42^{\prime} 56.69^{\prime \prime} \mathrm{E}\right)$ at an elevation of $5160 \mathrm{~m}$ and $5270 \mathrm{~m}$ respectively, which is the highest altitude ever recorded for an amphibian species.

At present, 20 species of Scutiger have been reported out of which 15 are endemic to China (Frost 2015). Only two species (S. sikimmensis, S. nyingchiensis) have been reported so far from India (Molur \& Walker 1998). In this paper, we report S. boulengeri for the first time from the Indian region taking the number of amphibian species known from India to 385 (Dinesh et al. 2015). The IUCN lists S. boulengeri as Least Concern (Ohler et al. 2004) and its population trend as unknown. In our study area in Sikkim, both species were quite abundant.

During our field survey we found S. sikimmensis between $2619 \mathrm{~m}$ to $4395 \mathrm{~m}$. It has been reported to occur at an altitude of $2500 \mathrm{~m}$ and has been found upto $4600 \mathrm{~m}$ in Sikkim (Chettri et al. 2011). We recorded S. boulengeri at $4005 \mathrm{~m}$ and upto $5270 \mathrm{~m}$.
Table 2. K2P distance between S. boulengeri from Fu et al. 2007 and the current study.

\begin{tabular}{|l|l|c|}
\hline Fu et al. (2007) & Current study & $\begin{array}{l}\text { Percent genetic } \\
\text { distance }\end{array}$ \\
\hline EF397271 & KR781481 & 2 \\
\hline EF397273 & KR781481 & 2 \\
\hline EF397272 & KR781481 & 3 \\
\hline EF397271 & KR781482 & 2 \\
\hline EF397273 & KR781482 & 2 \\
\hline EF397272 & KR781482 & 3 \\
\hline EF397271 & KR781483 & 2 \\
\hline EF397273 & KR781483 & 2 \\
\hline EF397272 & KR781483 & 3 \\
\hline
\end{tabular}

Compared to other terrestrial vertebrates, amphibians are relatively more vulnerable to the effects of rapid climate change as temperature can have a pervasive effect on amphibian biology, including reproduction because of their limited mobility (Donnelly \& Crump 1998). A recent study by Shrestha et al. (2012) has shown that the Himalaya are among the most vulnerable regions to future climate change. According 


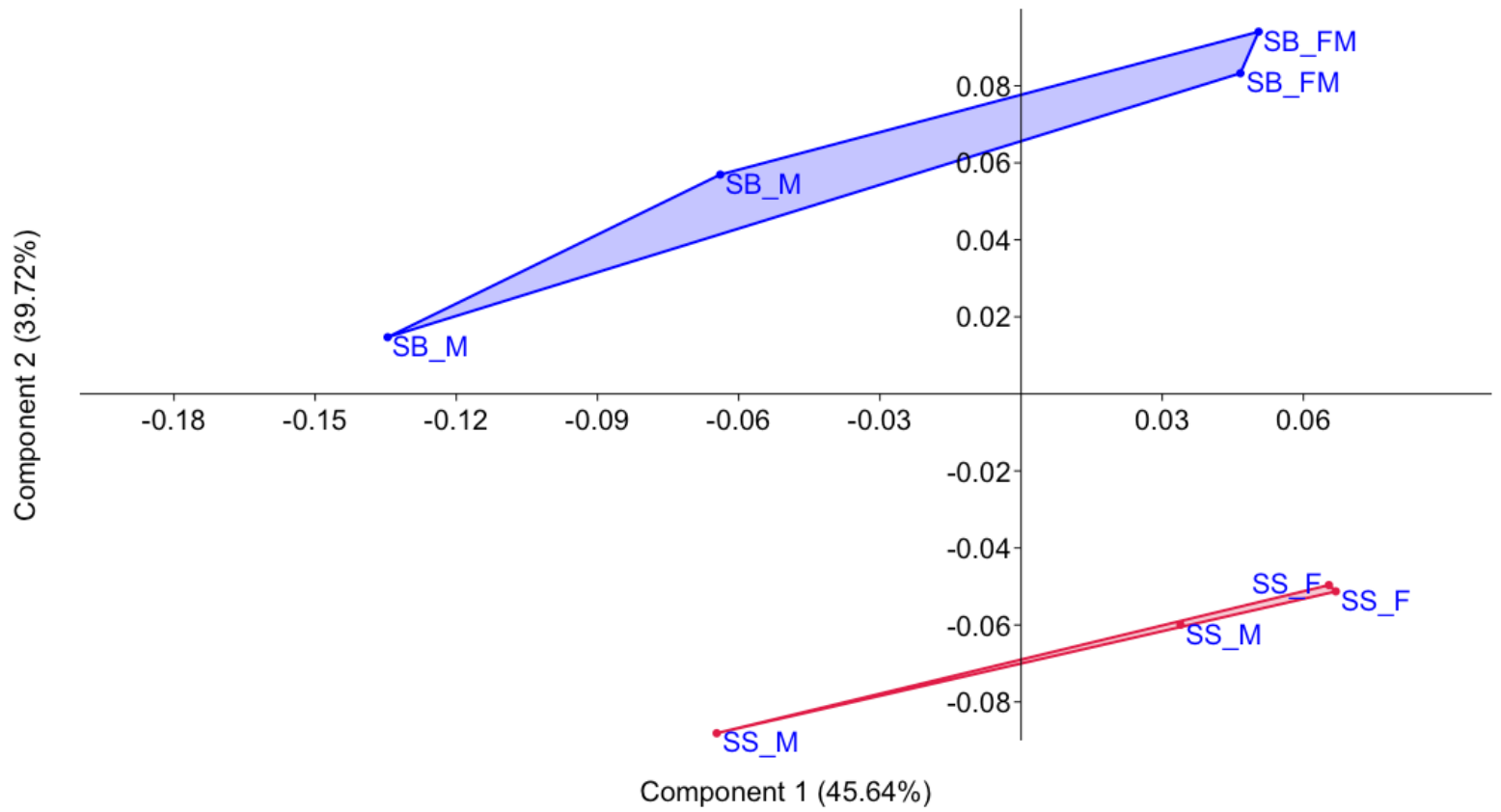

Figure 3. Principal component analysis of morphological characters for two species of Scutiger from Sikkim. Percent variation explained by each axis is provided in parenthesis.

(SS_M - Scutiger sikimmensis Male; SS_F - Scutiger sikimmensis Female; SB_M - Scutiger boulengri Male; SB_F - Scutiger boulengri Female)

to IPCC Himalayan glaciers are receding faster than in any other part of the world (IPCC 2007). For example, Zemu Glacier in Sikkim has retracted by $194 \mathrm{~m}$ between 1977 and 1984 with an average retreat of $27.7 \mathrm{~m} /$ year (IPCC 2007). Increasing mean temperature in the Himalaya has led to rapid melting of snow covers and glaciers bringing irreversible changes to the Himalayan cryosphere and rivers that are enriched by snowmelt (Bolch et al. 2012). This rapid climate change could have a serious impact on high altitude amphibians. Over $50 \%$ of amphibians are reported to be particularly susceptible to climate change (Bellard et al. 2012). Climate change also has implications on species differentiation of amphibians. A species restricted to a narrow altitudinal zone could migrate to higher altitudes due to global warming (Moritz \& Agudo 2013). The future of this extremely high altitude frog remains uncertain in the face of impending climate variation and global warming. Further studies on its physiology, temperature and moisture tolerance can give an insight on a batrachian strategy to adapt to climate change.

\section{SPECIES ACCOUNT}

Scutiger boulengeri (Bedriaga, 1898) Boulenger's Lazy Toad or Xizang Alpine Toad

\section{Materials examined $(n=4)$}

ATREE/Am/B03 and ATREE/Am/B08, northern Sikkim, Gurudongmar Complex 1, 28001'34.79"N \& 88 $42^{\prime} 51.72^{\prime \prime} \mathrm{E}$, altitude 5160m; ATREE/Am/ B02, northern Sikkim, Gurudongmar Complex 2, $28^{\circ} 00^{\prime} 34.17^{\prime \prime} \mathrm{N} \& 8^{\circ} 42^{\prime} 56^{\prime} 69^{\prime \prime} \mathrm{E}, 5270 \mathrm{~m}$; ATREE/Am/

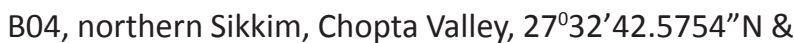
$88^{\circ} 18^{\prime} 47.0514^{\prime \prime} \mathrm{E}, 3970 \mathrm{~m}$.

\section{Morphological characters}

SVL: Male: $45 \mathrm{~mm}$ and $55 \mathrm{~mm}$; Female: $50 \mathrm{~mm}$ and $61 \mathrm{~mm}$.

Head flat, wider than long. Snout rounded. Snout tip protrudes beyond lower jaw. Supratympanal fold present. Tympanum indistinct. Eyes protruding. Pupil vertical. Fingers free. Subpalmar tubercles below I and IV fingers. Toes moderately webbed. One large and oblong metatarsal tubercle present. Canthus rostralis banded. Males have nuptial spines on fingers I,II and III and a pair of small axillary and a pair of large oval pectoral shields. The belly in reproductive males is dotted with numerous small warts with black tips. Similar granules also present near cloaca. The black tip wears off in preserved 
specimen if not fixed in formalin.

Coloration: Color in life olive or greenish-grey with numerous warts arranged somewhat in a longitudinal row, on the dorsal side. Ventral side yellowish in color. Dorsal pattern with slightly darker color than the body color. Dorsal pattern forms a bar between the eyes. Pupil golden.

\section{Habit and Habitat}

High altitude lakes, ponds and streams. As winter sets in towards the end of September, they come out of water and burrow into lose soil to hibernate. The hibernating individuals come out of the burrows and from under the rocks with the first rains (March/April).

Altitudinal range: $3000-5270 \mathrm{~m}$.

Breeding season: May to July

\section{Distribution}

Nepal, China (Qinghai, Xizang, Gansu Sichuan). This is the first report of this species from Sikkim, India.

IUCN status: Least Concern (LC).

\section{Scutiger sikimmensis (Blyth, 1855) Sikkim Snow Toad}

\section{Materials examined $(n=4)$}

ATREE/Am/B05 and ATREE/Am/B09, northern Sikkim,

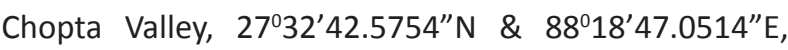
3970m; ATREE/Am/B06, Lachen, 27048'42.1986"N \& 88 $33^{\prime} 7.2^{\prime \prime} \mathrm{E}, 3273 \mathrm{~m} ;$ ATREE/Am/B07, Lachen, $27^{0} 35^{\prime} 16.0074^{\prime \prime} N \& 88^{\circ} 39^{\prime} 4.032^{\prime \prime} E, 2575 \mathrm{~m}$.

\section{Morphological characters}

\section{SVL: Male 42-62 mm; Female 45-67 mm}

Head wider than long. Snout rounded, slightly protrudes over the lower jaw. Tympanum hidden. Pupil vertical. Parotid glands present. Supratympanal fold in contact with the parotoids and does not reach the upper arm insertion. Fingers free. Toe webbing rudimentary. Metatarsal tubercle absent. Males have four-rounded sub-quadrangular or oval pectoral plate-like shields, two larger mid pectoral and two smaller axillary ones. Nuptual spines present on the upper side of fingers I and II and laterally on the third finger. During reproductive phase males develop tiny warts with black tips on the sides of the head, and on the anterior side of the lower jaw, dorsal region of the legs and on the ventral region of toes IV and V.

Coloration: Dorsal color in life olive green, brown or greyish-brown with numerous warts. Dorsal pattern is variable. Ventral region yellowish, uniform and smooth. Pupil golden.

\section{Habit and Habitat}

Found near mountain streams and rivers, grasslands, ox-bow lakes at higher elevation. They remain hidden under the stones. During breeding season males call from under the rocks at night.

Altitudinal range: 2800-4116 m.

Breeding season: June to August

\section{Distribution}

Nepal, India (West Bengal, Sikkim and Meghalaya) and China (Yadong, Cona and Nielamu).

IUCN status: Least Concern (LC).

\section{REFERENCES}

Acharya, B.K. \& L. Vijayan (2011). Butterflies of Sikkim with reference to elevational gradient in species, abundance, composition, similarity and range size distribution, pp. 207-220. In: Arrawatia, M.L. \& S. Tambe (eds.). Biodiversity of Sikkim: Exploring and Conserving $A$ Global Hotspot. Information and Public Relations Department, Government of Sikkim, xxviii +542pp.

Altschul, S., W. Gish, W. Miller, E. Myers \& D. Lipman (1990). Basic local alignment search tool. Journal of Molecular Biology 215(3): 403-410; http://dx.doi.org/10.1016/S0022-2836(05)80360-2

Bellard C., C. Bertelsmeier, P. Leadley, W. Thuiller \& F. Courchamp (2012). Impacts of climate change on the future of biodiversity. Ecology letters 15(4): 365-377; http://dx.doi. org/10.1111/j.1461-0248.2011.01736.x

Bolch, T., A. Kulkarni , A. Kääb , C. Huggel , F. Paul , J.G. Cogley, H. Frey, J.S. Kargel , K. Fujita, M. Scheel, S. Bajracharya \& M. Stoffel (2012). The State and Fate of Himalayan Glaciers. Science 336: 310-314; http://dx.doi.org/10.1126/science.1215828

Chettri, B., S. Bhupathy \& B.K. Acharya (2011). An overview of the herpetofauna of Sikkim with emphasis on the elevational distribution pattern and threats and conservation issues, pp. 233254. In: Arrawatia, M.L. \& S. Tambe (eds.). Biodiversity of Sikkim: Exploring and Conserving a Global Hotspot. Information and Public Relations Department, Government of Sikkim, xxviii +542pp.

Darriba, D., G.L. Taboada, R. Doallo \& D. Posada (2012). jModelTest 2: more models, new heuristics and parallel computing. Nature Methods 9: 772.

Dinesh, K.P., C. Radhakrishnan, B.H. Channakeshavamurthy \& N.U. Kulkarni (2015). Checklist of Amphibia of India, updated till January 2015 available at http://mhadeiresearchcenter.org/resources (online only).

Donnelly, M.A. \& M.L. Crump (1998). Potential effects of climate change on two neotropical amphibian assemblages. Climatic Change 39: 541-561.

Edgar R.C. (2004). MUSCLE: Multiple sequence alignment with high accuracy and high throughput. Nucleic Acids Research 32: 17921797.

Frost, D.R. (2015). Amphibian Species of the World: an online Reference. Version 6.0 Accessed on 5 July 2015.

Fu, J., C.J. Weadick \& K. Bi (2007). A phylogeny of the high-elevation Tibetan megophryid frogs and evidence for the multiple origins of reversed sexual size dimorphism. Journal of Zoology 273(3): 315325.

Hammer, Ø., D.A.T. Harper, P.D. Ryan (2001). PAST: Paleontological statistics software package for education and data analysis. 
Appendix 1. List of Scutiger spp. used in phylogenetic analysis.

\begin{tabular}{|l|l|l|l|}
\hline $\begin{array}{l}\text { Species name (as } \\
\text { indicated in the tree) }\end{array}$ & Accession No. & Locality & Reference \\
\hline S. boulengeri 1 & EF397271.1 & Gansu, China & Fu et al. 2007 \\
\hline S. boulengeri 2 & EF397273.1 & Sichuan, China & Fu et al. 2007 \\
\hline S. boulengeri 3 & EF397272.1 & Sichuan, China & Fu et al. 2007 \\
\hline S. boulengeri 4 & AY526202.1 & Sichuan, China & Zheng et al. 2004 \\
\hline S. boulengeri 5 & KR781481 & Sikkim, India & Current Study \\
\hline S. boulengeri 6 & KR781483 & Sikkim, India & Current Study \\
\hline S. boulengeri 7 & KR781482 & Sikkim, India & Current Study \\
\hline S. chintingensis 1 & EF397270.1 & Sichuan, China & Fu et al. 2007 \\
\hline S. chintingensis 2 & EF397269.1 & Sichuan, China & Fu et al. 2007 \\
\hline S. glandulatus 1 & EF397276.1 & Sichuan, China & Fu et al. 2008 \\
\hline S. glandulatus 2 & EF397275.1 & Sichuan, China & Fu et al. 2007 \\
\hline S. glandulatus 3 & EF397274.1 & Sichuan, China & Fu et al. 2007 \\
\hline S. mammatus 1 & EF397279.1 & Sichuan, China & Fu et al. 2007 \\
\hline S. sikimmensis 1 & KR781484 & Sikkim, India & Current Study \\
\hline S. sikimmensis 2 & KR781485 & Sikkim, India & Current Study \\
\hline S. sikimmensis 3 & KR781486 & Sikkim, India & Current Study \\
\hline S. sikimmensis 4 & KR781480 & Sikkim, India & Current Study \\
\hline S. tuberculatus 1 & EF397278.1 & Sichuan, China & Fu et al. 2007 \\
\hline Oreolalax strelingae 1* & KC569982.1 & Vietnam & Le 2013 \\
\hline Oreolalax popie 1* & AY526210.1 & Sichuan, China & Zheng 2004 \\
\hline Outgoups & & \\
\hline
\end{tabular}

* Outgroups

Palaeontologia Electronica 4(1): 1-9.

Hebbar, P., K.V. Gururaja \& G. Ravikanth (2015). Morphology, natural history and molecular identification of tadpoles of three endemic frog species of Nyctibatrachus Boulenger, 1882 (Anura: Nyctibatrachidae) from central Western Ghats, India. Journal of Natural History; http://dx.doi.org/10.1080/00222933.2015.10342 12

Hock, R.J. (1964). Animals in high altitudes: reptiles and amphibians, pp. 841-842. In: Dill, D.B., E.F. Adolph \& C.G. Wilber (eds.). Handbook of Physiology, Sect 4, Adaptation to Environment. American Physiological Society, Washington DC, 1056pp.

IPCC (2007). Contribution of working group II to the fourth assessment report of the intergovernmental panel on climate change, pp. 7-22. In: Parry, M.L., O.F. Canziani, J.P. Palutikof, P.J. van der Linden \& C.E. Hanson (eds.). Cambridge University Press, Cambridge, UK.

Mani, M.S. (1994). The Himalaya, its ecology and biogeography: a review. In: Pangtey, Y.P.S. \& R.S. Rawal (eds.). High Altitudes of the Himalaya (Biogeography, Ecology and Conservation). Gyanodaya Prakashan, Delhi, xii+418pp.

Mittermeier, R.A., P. Robles-Gil, M. Hoffmann, J.D. Pilgrim, T.B. Brooks, C.G. Mittermeier, J.L. Lamoreux \& G.A.B. Fonseca (2004). Hotspots Revisited: Earth's Biologically Richest and Most Endangered Ecoregions. CEMEX, Mexico City, Mexico, 390pp.

Molur, S. \& S. Walker (eds.) (1998). Report of the workshop 'Conservation Assessment and Management Plan for Amphibians of India' (BCPP-Endangered Species Project), Zoo Outreach Organisation, Conservation Breeding Specialist Group, Indiam 93pp.

Moritz, C. \& R. Agudo (2013). The Future of Species Under Climate Change: Resilience or Decline? Science 341: 504-508; http://dx.doi. org/10.1126/science.1237190

Ohler, A., K.C. Wollenberg, S. Grosjean, R. Hendrix, M. Vences, T. Ziegler \& A. Dubois (2011). Sorting out Lalos: description of new species and additional taxonomic data on megophryid frogs from northern Indochina (genus Leptolalax, Megophryidae, Anura). Zootaxa 3147: 1-83.

Ohler, A., P. Sanyal, F. Liang \& M.W.N. Lau (2004). Scutiger boulengeri. In: IUCN 2014. 2014 IUCN Red List of Threatened Species. Version 2015.2. <www.iucnredlist.org>. Downloaded on 11 August 2015.

Rambaut, A. (2009). FigTree, ver. 1.3.1. [Online]. Available:http:/tree. bio.ed.ac.uk/software/figtree/ Accessed on 21 December 2009.

Ronquist, F., M. Teslenko, P. Mark, D.L. Ayres, A. Darling, S. Höhna, B. Larget, L. Liu, M.A. Suchard \& J.P. Huelsenbeck (2011). MrBayes 3.2: Efficient bayesian phylogenetic inference and model choice across a large model space. Systematic Biology 61: 539-542; http:// dx.doi.org/10.1093/sysbio/sys029

Shrestha, U.B., S. Gautam \& K.S. Bawa (2012). Widespread climate change in the Himalayas and associated changes in local ecosystems. PLoS ONE 7(5): e36741; http://dx.doi.org/10.1371/ journal.pone.0036741

Silvestro, D. \& I. Michalak (2012). raxmIGUI: a graphical front- end for RAxML. Organisms Diversity and Evolution 12: 335-337; http:// dx.doi.org/10.1007/s13127-011-0056-0

Tamura, K., D. Peterson, N. Peterson, G. Stecher, M. Nei \& S. Kumar (2011). MEGA 5: Molecular evolutionary genetics analysis using maximum likelihood, evolutionary distance, and maximum parsimony methods. Molecular Biology and Evolution 28(10): 27312739; http://dx.doi.org/10.1093/molbev/msr121

Theobald, W. (1868). Catalogue of Reptiles in the Museum of the Asiatic Society of Bengal. Baptist Mission Press, Calcutta 37: 7-88.

Vences, M., Z.T. Nagy, G. Sonet \& E. Verheyen (2012). DNA barcoding of amphibians and reptiles, pp. 79-107. In: Kress, W.J. \& D.L. Erickson (eds.). DNA Barcodes: Methods and Protocols, Methods in Molecular Biology. Humana Press, New York City, USA, xv+470pp. 